\title{
Portfolio Building: The relationship with literacies in students' everyday lives
}

\author{
ANGELA BRZESKI
}

\section{Introduction}

This article explores some propositions about how students' everyday lives may interact with their success at learning in a large Further Education College in England. Some students, on paper, have all the appropriate entry qualifications, but still struggle to complete their courses. Indeed, some do not complete at all. So, what could be done to help these students achieve success? As a member of a large-scale research project team, I have been investigating the home literacies of further education students. Papen (2005a:14) points out that 'it is useful and necessary before any intervention can be planned, to carry out research which identifies learners' everyday literacy practices'. Of course, there are many other aspects of people's everyday lives that will influence their learning success. However, in this article I want to focus on the possibility of the influence of home literacy practices, by exploring how the reading and writing in the everyday lives of students could be drawn upon and utilized in order to help these students to succeed on their chosen college courses.

I start by providing some background about the Literacies for Learning in Further Education (LfLFE) research project on which this article draws. This is followed by a discussion of one of the theoretical arguments that are emerging from the LfLFE research project team following early data analysis. To illustrate this theoretical argument, I provide case studies of two further education students, studying on similar courses within the same vocational area of the same college. These case studies, generated from data derived from interviews and observations, detail the students' contrasting experiences of portfolio building. I suggest that the differences in students' experiences of portfolio building are influenced by the literacies in their everyday lives and the literacy practices they entail. The article concludes with recommendations as to what practical steps could be taken in future to assist students who might otherwise struggle or even fail to complete their chosen college courses. 


\section{The Literacies for Learning in Further Education (LfLFE) research project}

The Literacies for Learning in Further Education (LfLFE) project is a collaboration between two universities - Stirling and Lancaster - and four further education colleges - Anniesland, Perth, Lancaster and Morecambe and Preston.

The LfLFE research is grounded within a social practices approach to literacy. Rather than seeing literacy as a discrete set of skills to be acquired by the individual, the LfLFE research team's conceptual approach understands literacy as a social practice involving people, places, values, purposes, and a range of artefacts and media (Papen 2005b, Barton 2006). The project draws on work already done on literacy practices engaged in by people in schools, higher education and the community (see, for example, Barton and Hamilton 1998, Barton, Hamilton and Ivanič 2000, Hull and Schultz 2002, Pahl 2005, Smith 2005, Ivanič and Satchwell forthcoming), and seeks to extend the insights gained from these studies into further education. It aims to explore the literacy practices of students and those practices developed in different parts of the curriculum. This project involves examining how the literacy practices across the many domains of people's experience are mobilized and realized within different domains and their capacity to be mobilized and recontextualised elsewhere to support learning.

Through four partner FE colleges, the LfLFE research team worked closely with over 100 students, ranging in age from 16 to 58 . The case studies within this article are generated from data collected with two of these students, who were studying at the same college, on similar courses within the curriculum area of Painting and Decorating. In these case studies, the focus was on the literacy practice of portfolio building. To understand the literacy practices of the students in detail involves an understanding of what is going on from the perspective of those who are involved in these practices. Therefore, the team needed to research with students, rather than treating students as the subject of the research. The LfLFE team were committed to working collaboratively and participatively. The team were not carrying out research on these students, but were working with them in order to appreciate the role of reading and writing in their lives from their point of view (Brzeski and Fowler 2006).

\section{Resonance and Dissonance}

As mentioned in the introduction, many students are successful on their courses but some do not achieve their goals. Based on the evidence provided in the case studies, I suggest that the differences in students' experiences of portfolio building are resonant with their literacies in their 
everyday lives. This argument is consistent with examples provided by Mannion and Goodman (2006:3) of the LfLFE Project of how, for a given student on a given course, 'some aspects of what they read and write in their everyday lives seems to strike a chord with them in relation to their coursework'. The LfLFE Project team are currently exploring how the term 'resonance', a concept drawn from the field of music to describe when two objects are vibrating in sympathy, can usefully be applied to these experiences. Placing this within a theoretical context, it is proposed that literacy resonance (or a harmonious relationship) between college, home or workplace contexts is brought about through different aspects of the process of reading, writing and communicating. The diverse ways in which resonance can be experienced exist along different wavelengths, for example resonance of genre, resonance of audience, resonance of purpose and resonance of medium (for further discussion about resonance, see Goodman, Mannion and Brzeski (2007), Ivanič, Barton, Edwards, Fowler, Mannion, Miller, Satchwell and Smith (forthcoming 2009), Mannion (2006). Schwartz (1973) has a theory of resonance that argues that messages need to be designed to 'harmonize' with information already stored within an individual audience member. Only then will resonance occur. So, resonance takes place when the message stimuli in the communication process create meaning in a receiver's mind. Schwartz's resonance theory underlies his approach to persuasion. This theory maintains that the persuasiveness of a message is strengthened when it gives rise to a set of sympathetic experiences, memories, and values stored within receivers. This process leads to a recall of positive experiences or symbols encouraging the audience to make positive associations. Here, then, Schwartz is using the term 'resonance' to refer to 'meaning'. The LfLFE Project uses the term 'resonance' to refer to actually doing something, that is, the literacy practices, thus extending and applying Schwartz's theory. However, dissonance could also occur between aspects of the literacy demands of the course and the students' everyday literacy practices, thus preventing transference between the activities. Therefore, locating and identifying which aspects of the literacy practices contribute to dissonance may help teachers to provide ways of reducing students' difficulties on their courses.

\section{Portfolio Building as a Key Literacy Practice in Vocational Courses}

Schwartz' theory of resonance and dissonance can be applied to the case studies of two students observed and interviewed during the LfLFE project. College students have a wide range of literacy demands placed upon them, both inside and outside of the classroom. In the two case studies that are the subject of this article, the main literacy demand encountered by both students is that of the mandatory requirement to compile a portfolio of 
evidence. In vocational courses, a portfolio lists all of the performance criteria (standards), which the students have to prove they can meet. To provide this proof, the students write in how they have met these standards, providing practical evidence from their vocational area. The written claims are authenticated by a college tutor. The portfolios also include additional work produced by the students, including written assignments to prove knowledge and understanding. In the case studies, I focus on the curriculum area of painting and decorating. The two painting and decorating students have to compile a portfolio of evidence as part of their assessment. In addition to meeting all the standard requirements of portfolio building, these students also have to incorporate photographs that prove that a range of practical activities has been completed.

The contrasting experiences of the two students are presented and discussed in relation to the portfolio building process. I suggest that the differences in these students' experiences of portfolio building are to some degree dependent on their literacies in their everyday lives. In my case studies, both students are classed as 'adult' (i.e. are above 18 years of age). Both students are part-time, attending college two days per week. Out of these two days, half a day is spent in class covering painting and decorating theory and one and a half days is spent in practical workshops. In these workshops, the students are provided with small rooms within which they carry out all the required painting and decorating skills for example sanding, painting, papering and varnishing. In the workshops the students write down details of all the work that they do in a diary format. They also have photographs taken of them as they carry out the required practical activities. The student is then responsible for incorporating and organizing the diary accounts and the photographs into the portfolios.

In the case studies, I explore the students' home and work literacies and attempt to identify what it is that either helps (resonates) with or prevents (creates dissonance) with the 'mobilisation' of the students' literacy practices from outside to inside of college, or vice versa.

\section{The Literacy Practice of Portfolio Building - Two Contrasting Approaches}

\section{Gase Study One - 'Russell'}

At the time of the research, Russell was a Foundation Painting and Decorating student. He was in his first year, carrying out a basic introductory course. Russell is in his late 40 s/ early 50 s and he worked as a lecturer in Computing and IT at another local further education college before choosing to take early retirement. I first met Russell during the preliminary semester of his course. I met him in one of his practical workshops and he showed me his portfolio, which, even so early on in his 
course, was well structured, and was already illustrated with photographs showing him carrying out the various required practical activities. In addition to the compulsory components of the portfolio, Russell was also choosing to type up notes, in diary format, in a meticulous, detailed fashion, of all the practical activities he had carried out each day at college. These notes would be taken by Russell as he watched tutor demonstrations and listened to their commentary of every step of the demonstration, for example papering a ceiling. Russell then placed these diary pages in his portfolio as additional evidence.

Russell provided details of the steps that he goes through to create his diary pages. Russell explained that, when he started the course in September, he looked at the calendar for September to July (when his course concluded) and worked out the dates when he would be in college, ie the Monday and Tuesday of every week during term time. He then put these dates into a table in Word, allocating approximately one page for each day. Each page is framed within a box. Each week, by Wednesday or Thursday, he has typed into those boxes what he has done in the workshop sessions at college at the beginning of the week. As a result, Russell knows, from the day he started the course, what he has done in the practical workshop each week, for example demonstrations from his tutor and what he has carried out personally. In addition, Russell methodically takes photos, organizes them and neatly labels all the photos in his portfolio as an on-going process.

In the creation of his diary at college, Russell 'touch types', so he does not spend a lot of time physically typing this up. Russell explained to me that he intends to use his diary for reference purposes in the future, hence saving himself 'time' in his future pursuits. Therefore, Russell's desire and ability to manage his time resonates with his desire to turn his diary into a 'memory jogger'. What to some students may seem a laborious, longwinded task is, for Russell, an invested effort in the creation of a time-saving device in the future. In addition, the value that Russell places upon this diary equates to the value the college places on the creation of this diary, so this also creates resonance.

During the course of the research, I met with Russell's tutor on a number of occasions. Below are excerpts from these interviews regarding Russell's portfolio and his progress on his course:

[t is] an impressive portfolio ... I didn't expect anything else, to be honest, from Russell.

[I] $t$ is so well organised [and the use of the photographs] brings the whole portfolio to life.

[The diary is] absolutely accurate, accurate to the letter ... I have found it fascinating that he has gone into such detail. 
Russell is so interested, motivated, keen to learn that he would not allow anything to pass him by. He would not like to miss any information, so he has recorded everything. As a result of that, he has progressed so quickly and his standard of work is absolutely outstanding.

Russell managed to produce an exemplary portfolio, well in advance of the deadline given to him by his tutor. As can be seen from his tutor's comments, he was an extremely engaged student right from the start of the course, always keeping on top of his work and the portfolio building process. Why is this? To respond to this question, I now focus on Russell's home and then his work literacies.

\section{Russell's Home Literacies as a Resource for his College Literacies}

Russell's home life is mediated by many literacy practices. Each week, Russell creates a weekly shopping list. He has paper and a pen out in the kitchen permanently so that he can add to the list 'bit by bit during the week'. His list is 'organized around the plan of the supermarket for the sake of economy of time.'

Regarding his household bills, Russell has an established filing system:

... because of all the bills and everything coming in we need to organise it

so that there is no paper around the place. Again, it all revolves around time, knowing where everything is ...

Russell is also responsible for opening and sorting out all the junk mail received by the household. He explained: 'I tend to skim-read it ... get a flavour for it ... probably discard it but not all junk mail.' Russell then clarified that some is put to one side for reconsideration later, stating: 'I might come back to it to give it a closer reading and form a judgement about it, for example, is it a complete waste of time?'

These interview extracts suggest that time and time management is one of the keys to Russell's success on his chosen course. His home literacies have been tailored around making the best use of his time. Therefore, a detailed revelation of Russell's home literacies has led to an understanding of Russell's college literacy practices. At home, Russell's main objective of saving time is demonstrated through his literacy practices of creating a shopping list in advance of going to the supermarket, filing all the bills away in an orderly fashion and organising the junk mail. In college, Russell's intention is, again, to save time in future. This can be seen in his literacy practice of keeping a meticulous, detailed diary. In this case, therefore, the aspects of the student's home literacy practices which lead to his successful experience of portfolio building are time management and the student's perception of value. 


\section{Russell's Work Literacies as a Resource for his College Literacies}

Russell's work life was also mediated by a variety of literacy practices. Before joining his college course, Russell worked as an administrator, became a student and then, more recently, worked as a teacher. Russell explained:

When I was in teaching I used to do that [keep a diary] with my classes. It was something that I had done for 21 years, religiously keeping records of what I had done with classes, what I planned to do and what I had actually done ... I religiously wrote up every night when I went home at the end of the working day. This seems an extension of it here, really, keeping a diary.

He clarified that the process of keeping a diary 'comes from my work experience, both before I went into teaching ... before I became a student and then a student into a teacher. I think it is a throwback that I need to be organised ...'

Just as Russell kept a diary of his day-to-day activities in the workplace, he is again adopting this approach at college, methodically recording the details of work carried out in college on a day-by-day basis. However, it is important to note here that, although Russell kept a diary in his past employment, the organisation of the photos into a portfolio and the labelling of each photo are literacy practices that Russell has not carried out previously. This is a new literacy practice to Russell. Therefore, it is not simply a case of Russell producing an excellent portfolio in college because he is already familiar with all the required literacy practices

The requirements of the College course are very much resonant with Russell's work literacy practices. The literacy demands of building up a portfolio on his course very much resonate with the literacy demands within Russell's employment prior to him becoming a student, then as a student first time around and then as a lecturer. It is not that someone has to be an ex college lecturer to be an exemplary student. Russell is just one example and, as can be seen from my earlier comment regarding his organisation of his photographs, his college course has not only drawn on existing literary practices but required him to engage in new ones too. 


\section{Case Study Two - 'Paul'}

When I met Paul he was a student on the Intermediate Painting and Decorating course at the college. So, Paul was a second year student who had successfully completed his Foundation Course in the previous college year, including the compilation of a portfolio of evidence (very similar to the one described in Russell's Case Study above). Unlike Russell, however, Paul lacked motivation and had become increasingly disengaged from his course, resulting in being absent from classes and failing to meet his portfoliobuilding target dates.

Paul was in his mid 20s. In the year of the research, he had to compile another portfolio of evidence, identical in structure to the one he had put together the previous year. The only difference with the Intermediate portfolio is that the practical tasks he had to complete and record in his portfolio were more challenging. Therefore, bearing in mind that Paul had already managed, successfully, to put a portfolio together, I talked to him about his experience of portfolio building this year. In his interview, I was struck by how relaxed he appeared to be until we began to discuss his portfolio. Below are excerpts from my interview with Paul on this subject:

This is the one [showing me his Foundation year portfolio] I did last year, it just looks professional to me, and I won't be happy with myself if it is not done properly.

This year, I've not been motivated at all, I'm just sick of doing all this.

I have missed a few weeks, I've been off a month because I've been working and that ...

It is clear, then, from the above extracts, that Paul was becoming increasingly disengaged with his course. However, it was also clear to me that he was aware of what he needed to do to put his portfolio together, as he was able to explain the process to me in detail. He also appeared to have high standards as he stated that he 'won't be happy' with himself if the portfolio was not put together properly. However, despite this, he lacked motivation and had become increasingly disengaged with his course as he admitted that he had 'missed a few weeks'. This lack of progress is puzzling to his tutor, who shook his head when I spoke with him about Paul, declaring that Paul had 'already gone through it [the portfolio building process] once'. The tutor was at a loss to explain why Paul was finding it so problematic to put his portfolio together this year, stating 'it is strange, I don't know, I don't know'. So, why was Paul struggling so much? I now focus on Paul's home literacies. 


\section{Paul's Home Literacies as a Resource for his College Literacies}

It became clear when talking to Paul that he was engaged in a wide variety of literacy practices at home, most of which were collaborative. For example, Paul started working as a DJ with the help of his girlfriend as he told me 'my girlfriend bought me some decks' and 'she bought me two or three records a week and then I started collecting them'. In addition, Paul advertised his DJ functions to the general public with the assistance of a University student who designed the advertisements, from text provided by Paul, and posted them on the Internet. To expand his vinyl collection, Paul bought vinyls via the internet, using a friend's computer and with his friend's help to access the appropriate site: 'I do it on my mate's computer, go on certain websites... He gets us on; I just pick my vinyl ...'

Another interest that Paul had was that of owning his own property. Paul was a joint investor in a property, together with his father. He explained this investment to me: 'the house that I am in at the moment with my dad, I own I think it's a quarter of it, I gave him a lump sum towards that.' At the time of my discussion with Paul, he was also considering developing property, with his girlfriend, to sell on for a profit. Paul revealed the plans that he and his girlfriend had for her current house: 'we'll buy that, do that up and then hopefully sell it'.

At home, Paul enjoys reading books and writing with his girlfriend's children. He gave me an example of one collaborative reading and writing activity that he had recently carried out with his girlfriend's daughter: 'We got a cornflake box, cut it out and made wheels and that ... from a plan ... she had to write it in and then I had to write underneath...'.

In our discussion, Paul also revealed that he was revising for his driving theory test with the use of his girlfriend's friend's computer: 'her best mate ... she's got a computer ... I'll just practise on the computer'. However, Paul explained that he only used the computer after the friend had loaded up the programme for him.

Concerning his paperwork, Paul explained to me that he completed simple forms but usually in collaboration with his girlfriend, explaining: 'We'd probably do it between us.'

As these examples show, in his home life, Paul's literacy practices for purposes of his own choosing all involve a lot of collaboration with those around him. However, at college, as an Intermediate student, Paul has already put a portfolio together, and so there is an expectation by his tutors that he can put another one together quite easily and should therefore work much more independently. When I interviewed Paul, he spoke fondly of his tutor in his Foundation year at college who worked highly collaboratively with Paul during the portfolio building process. In the same interview, Paul 
was critical of his tutor this year, whom Paul referred to as being pedantic and unhelpful. He also perceived his current tutor's attempts to make him work alone as not caring about his progress. His tutor this year has reduced the level of collaboration during the portfolio building process, expecting Paul and his classmates to go through the process on their own. Therefore, the literacy demands of Paul's current course create dissonance with his home literacies. Much educational discourse of literacy (and literacies for learning) represents it as an individual and lone activity. However, this view, as can be seen in my example of Paul, can clash with research on literacies in everyday life. In Paul's case, many of his everyday literacies are carried out together with other people and it is this networking that allows him to accomplish and enjoy his literacy related activities. This argument is supported by Ivanič, Edwards, Satchwell and Smith (2007), who suggest that students preferred to work collaboratively, writing and/or reading together rather than independently. Collaboration is an aspect of literacy practices in many domains of life, particularly in the workplace but also, as we have seen in the case of Paul, in the home too.

\section{Achieving resonance}

So what can be done to help the literacy demands of college courses resonate with the home literacies of students? I do not suggest that what follows are definitive solutions, but rather that they are simply steps heading in the right direction and that we can help to facilitate resonance firstly by finding out about the home literacies of students at the start of their courses. With the knowledge and understanding of what may contribute to either resonance or dissonance, we are then in a position to bring changes into the classroom which can allow for more resonance and less dissonance. As can be seen in the examples of Russell and Paul, an appreciation of home literacies could contribute to this understanding. Of course, learners' lives and their relationship to learning are highly complex and achieving greater resonance is just one element that could be changed.

Also, we can try to avoid making assumptions of what a student can and cannot do simply on prior achievement alone. To be more congenial to the 'Pauls' who are trying to obtain a college qualification, resonance may be encouraged by continuing to offer one-to-one help with portfolio building or even introducing 'study buddies' (paired working). This suggestion is underpinned by the Vygotskian theory of development. Vygotsky (1981, cited in Dowley McNamee and Sivright 2002:172) argued that 'development begins in interactions among people; it does not begin within individuals themselves.' Vygotsky proposes that it is through others that we develop, which supports my suggestion of one-to-one help by the tutor or the introduction of 'study buddies'. Learning through others 'often involves mentoring provided by more culturally knowledgeable persons, usually 
elders, who engage in activity with less experienced or knowledgeable persons in a process known as scaffolding [authors' emphasis] (Bruner 1975, cited Lee and Smagorinsky 2000:2)'. However, the knowledge is not simply handed from one person to another. The exchange of information is considered to be mutual and 'cognitive change occurs within this mutually constructive process' (Lee and Smagorinksy 2000:2).

In addition to the changes in approach that could be taken by college staff, the awarding bodies (or examination boards) could also be more flexible. For example, in the case of the Painting and Decorating qualification undertaken by Paul, the requirements for 'demonstrating competence' might be brought more in line with the literacy demands of the industry. What is done in industry has been reformulated into a portfolio to meet the college's requirements. Thus, the actual practices of the industry are recontextualised in the pedagogic context. At present, within college the production of the portfolio is a very powerful literacy practice. There is great emphasis on the standardization of literacy accomplishments, tests and uniform learning outcomes. Students are ranked on a 'literacy ladder' in terms of what they cannot do rather than what they can do. This leads to a deficit model where those on the bottom rung, the 'Pauls' of this world, are positioned as lacking the skills that they need. The frameworks used to create the ladder are top-down ones, constructed in terms of what is seen to be vocationally relevant by the assessor (Paul's tutor) and the awarding body. There is no recognition of the validity of the students' own definitions, uses, aspirations and preferred ways of working so they are 'disempowering' in the sense that they are not negotiable or learner-centred and not locally responsive. In summary "They define what counts as "real literacy" and silence everything else' (Crowther, Hamilton and Tett, 2001:2). Paul, therefore, has little choice. He has to produce a portfolio, independently, as pedagogic convention dictates that he do so.

To help to empower Paul, his home literacy practices would make a good starting point for developing independence in the literacy practices of the industry, and that would be more value to him than completing the portfolio. This suggestion is supported by the humanistic school of learning, the main contributors being Maslow and Rogers. The humanistic psychologists believe that emotional factors, personal growth and development should be of highest value. They believe that 'schools and colleges [should] exist to meet the needs of the individual learner, not the other way round' (Petty 2004: 16). According to the humanists, the learner should be able to negotiate a unique 'learning contract' or 'action plan' for each individual. If Paul were to complete his own action plan, he could choose an assessment method that embraces his home literacy practices. Therefore, Paul's assessment methods would be customized to meet his own individual needs (Petty 2004). 
In conclusion, the concept of resonance has been found to be extremely illuminative within the LfLFE Project in its application to the contrast between two students on very similar courses within the same curriculum area who have responded totally differently to the portfolio building process. The focus on these two students has clearly illustrated the value of involving students and tutors in researching the resources that students can bring with them into the classroom, and in finding out how these resources might assist learning. This article suggests that there are aspects of literacy practices with which students identify in their everyday lives that have the potential to be mobilized within the classroom context. The home and work literacy practices of the students are therefore potential resources for learning and indeed for remodeling the pedagogic landscape within further education establishments.

\section{References}

Barton, David (2006) Literacy: An introduction to the ecology of written language (Second Edition), Blackwell, Oxford.

Barton, David, and Hamilton, Mary (1998) Local Literacies: Reading and writing in one community, Routledge, London.

Barton, David, Hamilton, Mary and Ivanič, Roz, eds, (2000) Situated Literacies: Reading and writing in context, Routledge, London.

Brzeski, Angela, and Fowler, Zoe (2006) Researching with Students: Challenges and possibilities, in Caldwell, J, Cleary, P, Crossan, B, Edwards, R, Gallacher, J, Gray, P, MacFarlane, K, McGavock, K, Mayes, N, Miller, K, Osborne, M, Remedios, R, Smith, J and Toman, N, eds, What a Difference a Pedagogy Makes: Researching lifelong Learning and Teaching, Conference Proceedings of 3rd International CRLL Conference, Glasgow, Centre for Research in Lifelong Learning, pp 706-711.

Crowther, Jim, Hamilton, Mary and Tett, Lynn (2001) Powerful Literacies, The National Institute of Adult Continuing Education (NIACE), Leicester, England.

Dowley McNamee, Gillian and Sivright, Sarah (2002) Community Supports for Writing Development Among Urban African American Children, in Hull, Glynda and Schultz, Katherine, eds, School's Out! Bridging Out-of-School Literacies with Classroom Practice, Teachers College, New York, pp 169-197.

Goodman, Ronny, Mannion, Greg and Brzeski, Angela (2007) Reading, Writing and Resonance: An experiential workshop for practitioners, research and practice, Adult Literacy fournal, vol 61 (Special issue for RAPAL Conference 2006, pp 10-14.

Hull, Glenda and Schultz, Katherine (2002) School's Out! Bridging Out-ofSchool Literacies with Classroom Practice, Teachers College, New York. 
Ivanič, Roz, Edwards, Richard, Satchwell, Candice and Smith, June (2007) Possibilities for Pedagogy in Further Education: Harnessing the abundance of literacy, British Educational Research Fournal, vol 33, no 5, pp 703-721.

Ivanič, Roz, Barton, David, Edwards, Richard, Fowler, Zoe, Mannion, Greg, Miller, Kate, Satchwell, Candice and Smith, June (forthcoming 2009) Improving Learning in College: Rethinking literacies across the curriculum, Routledge, London.

Ivanič, Roz and Satchwell, Candice (forthcoming) Boundary Crossing: Networking and transforming literacies in research processes and college courses', Fournal of Applied Linguistics, 2008.

Lee, Carol, D. and Smagorinsky, Peter (2000) Vygotskian Perspectives on Literacy Research, Cambridge University Press, Cambridge.

Mannion, Greg (2006) Viewpoint: 'Striking a Chord', Broadcast, vol 71, Summer, pp 40-41.

Mannion, Greg and Goodman, Ronnie (2006) Striking a Chord: Making coursework and curricula more resonant with students' everyday lives, Literacies for Learning in Further Education Project Newesletter, no 4, Spring/Summer 2006, pp 4.

Pahl, Kate (2005) Literacy and Education: Understanding the new literacy studies in the classroom, Paul Chapman, London.

Papen, Uta (2005a) Literacy and Development: What works for whom? Or, how relevant is the social practices view of literacy for literacy education in developing countries, International Fournal of Educational Development, vol 25, pp 5-17.

Papen, Uta (2005b) Adult Literacy as Social Practices - More than skills, Routledge, London.

Petty, Geoff (2004) Teaching Today, Third Edition, Nelson Thornes, Cheltenham.

Smith, June (2005) Mobilising Everyday Literacy Practices Within the Curriculum, Fournal of Vocational Education and Training, vol 57, no 3, pp 319-334.

Schwartz, Tony (1973) The Responsive Chord, Anchor, Garden City, New York. 
